\title{
Medidas acústicas de fonte glótica de vozes masculinas normais***
}

\author{
Acoustic measurements of the glottal source of normal male voices
}

\author{
Bárbara Costa Beber* \\ Carla Aparecida Cielo**
}

\begin{abstract}
*Fonoaudióloga. Mestre em Distúrbios da Comunicação Humana pela Universidade Federal de Santa Maria (UFSM-RS). Fonoaudióloga da Prefeitura Municipal de Mostardas e Cidreira - RS. Endereço para correspondência: Rua Juvenal Custódio Oliveira, 318. Palmares do Sul - RS. CEP 95540-000. (bcbfono@yahoo.com.br).

**Fonoaudióloga. Doutora em Linguística Aplicada pela Pontifícia Universidade Católica do Rio Grande do Sul. Professora Adjunta do Curso de Fonoaudiologia e do Programa de PósGraduação em Distúrbios da Comunicação Humana da UFSM - RS.

****Trabalho Realizado no Departamento de Fonoaudiologia da UFSM - RS.
\end{abstract}

Artigo Original de Pesquisa

Artigo Submetido a Avaliação por Pares

Conflito de Interesse: não

Recebido em 05.06.2009.

Revisado em 28.08.2009; 22.03.2010;

05.04.2010; 13.06.2010.

Aceito para Publicação em 16.08.2010.

\begin{abstract}
Background: acoustic vocal characteristics of young male adults. Aim: to characterize the acoustic measurements of the glottal source of young male adults with normal voices and larynx and to compare these results to the standard measurements proposed by the software used for this assessment. Method: 25 young male individuals (20 to 40 years), who presented normal voices and larynx, were selected. All subjects had the prolonged vowel [a] emission analyzed by the Multi Dimensional Voice Program Advanced (MDVPA). The Lilliefords test, with a significance level of 5\%, was used to verify the normal distribution of the results of each measurement. The parameters with normal distribution had their means compared to the standard measurements proposed by the program using the $\mathrm{T}$ Test (significance level of 5\%). Results: the group was characterized by 18 means of acoustic measurements. Measurements of frequency disturbance and amplitude were the ones that most differed from the standard measurements, presenting higher values. Approximately half of the measurements presented normal distribution. Conclusions: the measurements of jitter and shimmer of young male adults with normal voices and larynx were high. Measurements of fundamental frequency, noise and instability remained within the expected values. Approximately half of the measurements presented normal distribution prevailing those of jitter and shimmer, indicating that these measurements can be used as a reference.
\end{abstract}

Key Words: Voice; Men's Health; Speech Acoustics.

\section{Resumo}

Tema: características vocais acústicas de homens jovens adultos. Objetivo: caracterizar as medidas acústicas da fonte glótica de homens adultos jovens com voz e laringe normais e compará-las ao padrão do software usado. Método: foram selecionados 25 sujeitos do sexo masculino, voz e laringe normais, faixa etária de adulto jovem (20 a 40 anos). Todos tiveram a emissão da vogal [a] analisada pelo Multi Dimensional Voice Program Advanced (MDVPA). Foi realizada a distribuição normal dos resultados de cada medida do programa através do Teste Lilliefords, com nível de significância de 5\%. Os parâmetros que tiveram distribuição normal tiveram suas médias comparadas ao padrão de normalidade proposto pelo programa através do Teste t, com nível de significância de 5\%. Resultado: o grupo foi caracterizado por 18 médias de medidas acústicas. As medidas de perturbação de frequência e de amplitude foram as que mais se distanciaram da normalidade, apresentando valores altos. Aproximadamente a metade das medidas apresentou distribuição normal. Conclusão: em homens adultos jovens com voz e laringe normais, as medidas de jitter e de shimmer mostraram-se altas e as de frequência fundamental, de ruído e de instabilidade ficaram dentro do esperado. Aproximadamente a metade das medidas apresentou distribuição normal, predominando as de jitter e de shimmer, podendo ser utilizadas como referência.

Palavras-Chave: Voz; Saúde do Homem; Acústica da Fala. 


\section{Introduction}

The Multi Dimension Voice Program Advanced (MDVPA) of Kay Elemetrics ${ }^{\circledR}$ is a program of acoustic analysis of the voice that calculates up to 33 measures of vocal production, represents them graphically and compares them to its own normative values1-2.

Many vocal parameters depend on the sex, facial type, race and age range3-8, what makes that every subject, or group of subjects, present particular vocal characteristics.

Numerous studies have tried to normatize acoustic vocal parameters to characterize the human voice. However, when the results are compared to normality patterns in literature, differences are evident. The differences found may be related to the software of the voice analysis or the subject4.

Because the national and the international studies that propose base-measures for the glottal acoustic evaluation of the voices of different sexes are scarce, this study aimed to characterize the acoustic measures of the glottal source of young adult males with normal voice and larynx, using the MDVPA and compare them to the standard of the program.

\section{Method}

This is a study that has been approved by the Committee of Research Ethics (CEP) of the institution of origin (0087.0.243.000-07); it is a quantitative, transversal and exploratory analysis, through data bank collection (first stage) and field data collection (second stage).

The data from the first stage were stored in the data bank of the Voice Laboratory of the institution and had not been used then. The subjects signed the Term of Free and Clear Consent (TCLE) that the schoolclinic offers and where it reads that the collected data may be used in future researches.

The second stage began after all the subjects read and the signed the specific TCLE used in the research, according to the resolution 196/96, of the National Committee of Research Ethics (CONEP).

The study group was constituted intentionally. The inclusion criteria were: male subjects; with otorhino-laryngeal diagnosis of normal larynx; age range of young adult (20 to 40 years old); agreement with the TCLE.

The exclusion criteria were: medical record for neurologic, psychiatric, endocrinologic or gastric disease; vocal complaints (hoarseness, vocal fatigue, voice gaps, etc.); auditory-perceptive vocal alterations; flu; breathing allergies or other diseases that may impair the vocal performance; drinking or smoking habits; previous speech-therapy treatment and/or previous oto-rhino-laryngeal treatment; hearing alterations; stomatognathic system alterations; being a singer; aged under 20 years old; aged over 40 years old.

The subjects of the first stage were selected through the analysis of all their stored evaluations, aiming the inclusion and exclusion criteria. During the second stage, after signing the TCLE, answering a questionnaire, having an oto-rhino-laryngeal evaluation and a speech-therapy selection, which included an oral myofunctional evaluation and auditory selection, and also an analysis of the voice quality, the subjects that fitted the inclusion and exclusion criteria were selected.

For the auditory selection, it was used a pure tone scanning in the frequencies of 500, 1000, 2000 and $4000 \mathrm{~Hz}$ at $25 \mathrm{~dB}$, only through the airway9.

For the exclusion of subjects with perceptiveauditory vocal alterations, the voices were classified in "with" or "without" the presence of noise (soprosity, roughness, hoarseness), tension (compressed voice or strangled-tense voice), instability (trembling, sonority breaks, frequency breaks), inadequate pitch, having possible unbalances of the glottal source 10 . This evaluation was performed with the recordings of spontaneous speech of the data bank in the first stage and with the interview recording in the second stage and all the subjects that showed any of the aforementioned alterations were excluded, even if they had an oto-rhino-laryngeal diagnose of normal larynx.

The oto-rhino-laryngeal exam was performed by an oto-rhino-laryngologist through a video laryngoscope. The other exams, which are necessary for the definition of the inclusion or exclusion of the subjects in the research, as well as the data collection, were performed by one of the speech therapists who is in charge of the research and has a master degree and experience in the voice area. The interpretation of the exams for the inclusion or exclusion was not blind.

Twenty and five young adult males were selected (13 in the first stage and 12 in the second stage) with ages ranging from 20 to 39 years old (average of 28 years old).

The collection of the subject voices of the first stage had already been done previously; the same steps were followed for the second stage subjects. The sustained emission of the vowel [a] was collected with the subject standing and with arms along the body. The microphone attached to the digital recorder SONY, model ICD-P210 was put in an angle of 90, $4 \mathrm{~cm}$ from the mouth5, 10-11. The emission was sustained in habitual frequency and intensity, after a deep breath and during maximum phonation time (TMF)5. 
For the acoustic analysis of the voices, the vocal attack was excluded and because of this, the first 3,5 seconds of the emission of the vowel [a] were excluded5,10,12.

The analysis of the emissions was performed using the MDVPA that provided the measures, 28 measures of which were useful for this study.

The results were compared to the average and to the normality threshold suggested by the program, except for the f0 parameter that was compared to the normality range for men $(80-150 \mathrm{~Hz})$ proposed by a Brazilian study, once it had values proposed by other studies13.

For the normal distribution of the data, the Lilliefords test was used (significance level of 5\%). In the parameters where the distribution of the data was normal, it was possible to apply the t Test (significance level 5\%), in order to compare the average obtained in the study with the normality standards proposed by the MDVPA. When the distribution of some data is not normal, that happens because the result of a subject differs a lot from the others, thus the resulting average may not be representative from the group. However, the averages of the measures without normal distribution will be discussed, because these also present important possibilities.

\section{Resultados}

Tables 1, 2 and 3 present the averages of all the measures obtained for the group studied and the results of the statistic analysis.

TABLE 1. Results of the frequency measures of males with normal voice and larynx.

\begin{tabular}{ccccccccccc}
\hline \multirow{2}{*}{ Parameter } & \multicolumn{3}{c}{ Results } & \multicolumn{3}{c}{ Program Standard } \\
& Average & SD & CV & Normality Threshold & Average & Threshold & SD & CV & - \\
\hline f0 (Hz) & 120,16 & 23,72 & 0,20 & $\mathrm{p}<0,05$ & $80-150 \mathrm{~Hz}$ & $150 \mathrm{~Hz}^{* * *}$ & - & - \\
fhi (Hz) & 155,88 & 110,19 & 0,71 & $\mathrm{p}<0,01$ & 150,08 & - & 24,36 & 0,16 & - \\
flo (Hz) & 110,53 & 25,05 & 0,23 & $\mathrm{p}>0,20 *$ & 140,42 & - & 23,73 & 0,17 & 0,00000 \\
STD de f0 & 3,03 & 3,13 & 1,03 & $\mathrm{p}<0,01$ & 1,35 & - & 0,68 & 0,50 & - \\
\hline
\end{tabular}

*Follows normal distribution. Lilliefords Test; **Within the normality of the program. T Test. *** According to Behlau, Pontes and Tosi (1985). Abbreviations: Coefficient of Variation $=$ CV, Standard Deviation $=$ SD, f0 $=$ Fundamental Frequency, fhi $=$ Maximum Fundamental Frequency, flo = Minimum Fundamental Frequency, STD of f0 = Standard Deviation of the Fundamental Frequency.

TABLE 2. Results of the frequency perturbation and intensity measures of males with normal voice and laryn $x$.

\begin{tabular}{ccccccccccc}
\hline Parameter & & \multicolumn{3}{c}{ Results } & & \multicolumn{3}{c}{ Prog ram Standart } \\
& Average & SD & CV & $\begin{array}{c}\text { Normality } \\
\text { Threshold }\end{array}$ & Average & Threshold & SD & CV & p \\
\hline Jita (us) & 128,25 & 100,28 & 0,78 & $\mathrm{p}<0,05$ & 41,66 & 83,20 & 36,48 & 0,88 & - \\
Jitt (\%) & 1,51 & 1,13 & 0,75 & $\mathrm{p}>0,20^{*}$ & 0,59 & 1,04 & 0,54 & 0,91 & 0,00044 \\
RAP (\%) & 0,89 & 0,69 & 0,78 & $\mathrm{p}>0,20^{*}$ & 0,35 & 0,68 & 0,33 & 0,97 & 0,00068 \\
PPQ (\%) & 0,91 & 0,74 & 0,82 & $\mathrm{p}<0,10^{*}$ & 0,34 & 0,84 & 0,29 & 0,86 & 0,00084 \\
sPPQ (\%) & 1,22 & 0,90 & 0,74 & $\mathrm{p}<0,01$ & 0,56 & 1,02 & 0,30 & 0,53 & - \\
vf0 (\%) & 2,56 & 2,65 & 1,03 & $\mathrm{p}<0,01$ & 0,94 & 1,10 & 0,43 & 0,46 & - \\
ShdB (dB) & 0,42 & 0,40 & 0,95 & $\mathrm{p}>0,20^{*}$ & 0,22 & 0,35 & 0,09 & 0,39 & 0,01876 \\
Shim (\%) & 4,54 & 4,25 & 0,94 & $\mathrm{p}<0,10^{*}$ & 2,52 & 3,81 & 1,00 & 0,40 & 0,02559 \\
APQ (\%) & 3,87 & 3,69 & 0,95 & $\mathrm{p}>0,20^{*}$ & 1,99 & 3,07 & 0,81 & 0,41 & 0,01753 \\
sAPQ (\%) & 6,61 & 6,31 & 0,95 & $\mathrm{p}<0,15^{*}$ & 3,06 & 4,23 & 1,34 & 0,44 & 0,00957 \\
vAm (\%) & 14,47 & 13,14 & 0,91 & $\mathrm{p}<0,01$ & 7,71 & 8,20 & 3,93 & 0,51 \\
\hline
\end{tabular}

*Follows normal distribution. Lilliefords Test ; **Within the normality of the program. T Test. Abbreviations: Jita = Absolute Jitter, Jitt $=$ Percentage Jitter, RAP $=$ Relative Average of Perturbation, PPQ $=$ Pitch Perturbation Quotient, sPPQ $=$ soften ed Pitch Perturbation Quotient, vf0 = Coefficient of Variation of Fundamental Frequency, Sh $\mathrm{dB}=$ Shimmer in $\mathrm{dB}$, Shim $=$ Percentage Shimmer, APQ = Amplitude Perturbation Quotient, sAPQ = softened Amplitude Perturbation Quotient, vAm = Coefficient of Amplitude Variation. 
TABLE 3. Results of the noise measures, voice break measures, deaf segments, sub harmonic components, and vocal tremble of men with normal voice and larynx.

\begin{tabular}{|c|c|c|c|c|c|c|c|c|c|}
\hline \multirow{2}{*}{ Parâmetro } & \multicolumn{4}{|c|}{ Resultados } & \multicolumn{4}{|c|}{ Padrão do Programa } & \multirow{2}{*}{$\mathbf{p}$} \\
\hline & Média & DP & $\mathbf{C V}$ & Normalidade & Média & Threshold & DP & CV & \\
\hline NHR & 0,18 & 0,06 & 0,35 & $\mathrm{p}<0,01$ & 0,12 & 0,19 & 0,01 & 0,11 & - \\
\hline VTI & 0,05 & 0,02 & 0,32 & $\mathrm{p}<0,05$ & 0,05 & 0,06 & 0,02 & 0,31 & - \\
\hline SPI & 8,79 & 3,53 & 0,40 & $\mathrm{p}<0,10^{*}$ & 6,77 & 14,12 & 3,78 & 0,56 & 0,00870 \\
\hline DVB (\%) & 0,27 & 0,94 & 3,49 & $\mathrm{p}<0,01$ & 0,20 & 1,00 & 0,10 & 0,50 & - \\
\hline NVB & 0,20 & 0,71 & 3,54 & $\mathrm{p}<0,01$ & 0,20 & 0,90 & 0,10 & 0,50 & - \\
\hline DUV (\%) & 4,33 & 11,92 & 2,75 & $\mathrm{p}<0,01$ & 0,20 & 1,00 & 0,10 & 0,50 & - \\
\hline NUV & 5,32 & 14,66 & 2,75 & $\mathrm{p}<0,01$ & 0,20 & 0,90 & 0,10 & 0,50 & - \\
\hline DSH (\%) & 0,43 & 1,80 & 4,24 & $\mathrm{p}<0,01$ & 0,20 & 1,00 & 0,10 & 0,50 & - \\
\hline NSH (\%) & 0,52 & 2,20 & 4,23 & $\mathrm{p}<0,01$ & 0,20 & 0,90 & 0,10 & 0,50 & - \\
\hline Fftr $(\mathrm{Hz})$ & 3,44 & 2,28 & 0,66 & $\mathrm{p}>0,20^{*}$ & 3,66 & - & 3,73 & 1,02 & $0,63316^{* *}$ \\
\hline Fatr (Hz) & 1,78 & 2,81 & 1,58 & $\mathrm{p}<0,01$ & 2,73 & - & 1,76 & 0,64 & - \\
\hline FTRI (\%) & 0,38 & 0,30 & 0,78 & $\mathrm{p}>0,20^{*}$ & 0,31 & 0,95 & 0,14 & 0,45 & $0,23519 * *$ \\
\hline ATRI (\%) & 1,36 & 2,68 & 1,97 & $\mathrm{p}<0,01$ & 2,13 & 4,37 & 1,36 & 0,64 & - \\
\hline
\end{tabular}

*Follows normal distribution. Lilliefords Test ; **Within the normality of the program. T Test. Abbreviations: NHR $=$ Noise Harmonic Rate, VTI = Voice Turbulence Index, SPI = Soft Phonation Index, DVB = Degree of Voice Breaks, NVB $=$ Number of Voice Breaks, DUV = Degree of silence - periods without voice, NUV $=$ Number of non vocalized Segments, DSH $=$ Degree of Sub Harmonic Components, NSH = Number of Sub Harmonic Segments, Fftr $=$ frequency of tremble frequency, Fatr $=$ Tremble Amplitude Frequency, FTRI = Frequency of Tremble severity ind ex, ATRI = Amplitude Tremble severity Index.

\section{Discussion}

Concerning the frequency measures fundamental frequency (f0), maximum fundamental frequency (fhi) and Standard Deviation (STD) of f0, they did not have normal distribution, whereas the minimum fundamental frequency (flo) did.

In this research, $\mathrm{f} 0$ was within the normality range for male voice proposed by the study used for comparison13, agreeing also with other studies5,10,14-15. Also, f0 is the measure that characterizes the human voice the most and the one that shows the most agreement among the studies16, as well as it occurred with this one.

The results obtained for the flo and fhi showed great variability during the sustaining of f0, thus suggesting phonation instability. This variability may also be justified by the fact that the subjects do not have skilled voices, because if there is pneumophonoarticulatory coordination (CPFA), consequently there is a more stable emission17.

About the STD of f0, it was possible to observe that the average was superior to that one of the program and to the ones found in other studies1819, raising the question that these voices showed great variation in the sustaining of f0, a fact corroborated by the values of flo, fhi, coefficient of variation of the fundamental frequency (vfo) and coefficient of variation of amplitude (vAm).
Among the measures of frequency perturbation, Jitt, relative average of perturbation (RAP) and quotient of pitch perturbation (PPQ) followed normal distribution and their averages were considered significantly above normality. The Jita measures, softened pitch perturbation quotient (sPPQ) and vf0 did not have normal distribution, but it was observed averages that were superior to the threshold of the program, in agreement with the research that also found the average of SPPQ above the threshold of normality.

Other studies found averages of frequency perturbation below the threshold of normality of the MDVP2,18. However, when the ranges of normality found in another study18 are considered, for a similar population, all the measures of this research can be considered within normality. Studies show that these measures may appear bigger for men in relation to women, however not always with statistic significance2,13,15,18,20. The Jitter appears correlated to vocal noise or to hoarseness in some studies14,21, so usually it is bigger in men, once male voices are noisier because of lower $\mathrm{f} 0$.

In the analysis of the measures of intensity perturbation, it was obtained normal distribution for Shimmer in dB (ShdB), Percentage Shimmer (Shim), Amplitude Perturbation Quotient (APQ) and softened 
Amplitude Perturbation Quotient (sAPQ), except for the vAm, with bigger normal distribution among the subjects in this class of measures. All of them showed averages above the expected by the MDVPA and by the results of another research20. However, one study also obtained measures of intensity perturbation bigger than the threshold of normality of the MDVPA for male with normal voice and larynx18, agreeing with the findings of this study.

Among the noise measures, the Soft Phonation Index (SPI) followed normal distribution and its average, despite of being within the threshold of normality of the program, was not considered statistically normal. The other measures [NoiseHarmonic Rate (NHR) and Voice Turbulence Index (VTI)] did not show normal distribution, but had averages within the normality of the program. Other studies also found these measures within the normality of the MDVPA2,18. Normal vocal samples are expected to have low values of noise measures5, whereas larynxes with lesions are expected to show augmented noise measures.

The distribution of the voice break measures (Degree of Voice Break - DVB and Number of Voice Breaks - NVB) was not normal, but its averages were within the normality proposed by the MDVPA, showing that the voices studied did not show interruptions or breaks because the sample was composed of subjects with voice and larynx considered normal.

The distributions of the measures of deaf or non vocalized segments were not normal and the average of the number of non vocalized segments (NUV) was above that expected by the program, suggesting a great quantity of non vocalized segments that may reflect as irregularities or noise to the emission5,18.

Among the measures of vocal tremble, it was obtained a normal distribution of the frequency of the tremble frequency (Fftr) and the index of severity of the tremble frequency (FTRI) and their averages were considered statistically normal. The averages of tremble amplitude frequency (Fatr) and of the index of severity of tremble amplitude (ATRI) were within the normality of the program. Thus, it is possible to

\section{References}

1. Deliyiski D. Acoustic model and evaluation of pathological voice production. Kay Elemetrics; 1993. say that , concerning the long term variations, there was not vocal tremble, agreeing with the literature that claims that the vocal tremble is a manifestation of neurologic alterations on the voice 5,23.

Concerning the measures of sub harmonic segments, high values of this measures are a consequence of the vibration of other structures (diplophonia) or fry, and low values are related to the presence of noise to the emission5,18. Despite of the fact that there wasn't a normal distribution of these measures in this study, the measures were within the expected values by the program, demonstrating that the vocal sign analyzed was generated by only one source. However, the measures may suggest some level of vocal noise, a fact that was corroborated by the values off Jitter and Shimmer obtained.

In this research, the test of normal distribution was of great value to show that few analyzed measures had normal distribution among the 25 male subjects. That confirms another study of normal voice, which also found variation inter-subjects 24 .

It has become necessary to verify the existence of normative patterns for every population, with bigger groups of subjects, questioning the determination of normality by the programs of acoustic analysis that, like the MDVPA, was determined by 68 people, only 15 with normal voice (7 men and 8 women) and 53 with laryngeal problems (25 men and 28 women)1.

\section{Conclusion}

In young adult males with normal voice and larynx, the measures of NHR, VTI, SPI, NVB, DVB, sub harmonic components degree (DSH), number of sub harmonic segments (NSH), ATRI and FTRI showed averages within the normality range of the program, being significant only the Fftr and FTRI and the f0 showed average within the adopted criteria. About half of the measures (flo, Jitt, RAP, PPQ, ShdB, Shim, APQ, sAPQ, SPI, Fftr and FTRI) showed normal distribution, predominantly the Jitter and the Shimmer, which may be used as reference.
2. Godino-Llorente JI, Osma-Ruiz V, Sáenz-Lechón N, Cobeta-Marco I, González-Herranz R, Ramírez-Calvo C. Acoustic analysis of voice using WPCVox: a comparative study with Multi Dimensional Voice Program. Eur Arch Otorhinolaryngol. 2008;265(4):465-76. 
3. Xue SA, Fucci D. Effects of race and sex on acoustic features of voice analysis. Percept mot skills. 2000;91(3): 951-8.

4. Carrara-De Angelis E, Cervantes O, Abrahão M. Necessidade de medidas objetivas da função vocal: avaliação acústica da voz. In: Ferreira LP, Costa H. O. Voz Ativa: Falando sobre a Clínica fonoaudiológica. São Paulo: Roca; 2001. p. 53-72.

5. Barros APB, Carrara-De Angelis E. Análise acústica da voz. In: Dedivitis RA, Barros APB. Métodos de Avaliação e Diagnóstico da Laringe e Voz. São Paulo: Lovise; 2002. p. 200-221.

6. González, J. Formant frequencies and body size of speaker: a weak relationship in adults humans. Journal of Phonetics. 2004;32(2):277-87

7. Xue SA, Hao GJP, Mayo R. Volumetric measurements of vocal tracts for male speakers from different races. Clinical Linguistics \& Phonetics. 2006;20(9):691-702.

8. Iseli M, Shue YL, Alwan A. Age, sex, and vowel dependencies of acoustic measures related to the voice source. Journal of the Acoustical Society of America. 2007; 121(4):2283-95.

9. Barrett KA. Triagem Auditiva de Escolares. In: Katz J. (Org). Tratado de Audiologia Clínica. 4. ed. São Paulo: Manole; 1999. p. 472-85.

10. Behlau M, Madazio G, Feijó D, Pontes P. Avaliação de Voz. In: Behlau, M. Voz: o livro do especialista vol I. Rio de Janeiro: Revinter; 2001. p.85-245

11. Deliyski D, Evans MK, Shaw HS. Influence of data acquisition environment on accuracy of acoustic voice quality measurements. J Voice. 2005;19(2):176-86.

12. Oguz H, Demirci M, Safak MA, Arslan N, Islam A, Kargin s. Effects of unilateral vocal cord paralysis on objective voice measures obtained by Praat. European Archives of Oto-Rhino-Laryngology. 2007;264(3):257-62.

13. Behlau MS, Pontes P, Tosi O. Determinação da frequência fundamental e suas variações em altura (jitter) e intensidade (shimmer) para falantes do Português Brasileiro. Acta AWHO. 1985;4(1):5-9.
14. Pinho SMR, Camargo Z. Introdução à análise acústica da voz e da fala. In: Pinho SMR. Tópicos em Voz. Rio de Janeiro: Guanabara-Koogan; 2001. p. 19-44.

15. Felippe ACN, Grillo MHMM, Grechi TH. Normatização de medidas acústicas para vozes normais. Revista Brasileira de Otorrinolaringologia. 2006;72(5): 659-64.

16. Guimarães I, Abberton E. Fundamental frequency in speakers of portuguese for different voice samples. J Voice. 2005;19(4):592-606.

17. Saxon KG, Schneider CM. Vocal exercise physiology. California: singular Publishing group; 1995. p. 69-71.

18. Gonzáles J, Cervera T, Miralles JL. Análisis acústico de la voz: fiabilidad de um conjunto de parámetros multidemensionales. Acta Otorrinolaringol Esp. 2002;53: 256-68.

19. Smits I, Ceuppens P, Bodt MS. A comparative study of acoustic voice measurements by means of Dr. Speech and Computadorized Speech Lab. Journal of Voice. 2005;19(2): 187-96.

20. Nicastri M, Chiarella G, Gallo LV, Catalano M, Cassandro E. Multidimensional voice program (MDVP) and amplitude variation param, eters in euphonic adult subjects. Normative study. Acta Otorhinolaryngol Ital. 2004;24:337-41.

21. Camargo ZA, Madureira S. Análise acústica: revisão crítica de estudos no campo das disfonias. In: Ferreira LP, Befi-Lopes DM, Limongi SCO (Org.) Tratado de Fonoaudiologia. São Paulo: Roca; 2004. p. 25-33.

22. Jotz GP, Cervantes O, Abrahao M, Settanni FAP, de Angelis EC. Noise-to-harmonics ratio as an acoustic measure of voice disorders in boys. Journal of Voice. 2002;16(1): 28-31.

23. Dromey C, Smith ME. Vocal tremor and vibrato in the same person: acoustic and electromyographic differences. Journal of Voice. 2008;22(5):541-5.

24. Putzer M, Wokurek W. Multiparametric description of voice quality for normal male and female voices based on acoustic analyses. Laryngo-Rhino-Otologie. 2006;85(2): 105-12. 